\title{
Improvements in Steroid Screening in Doping Control with Special Emphasis to GC-MS Analytical Conditions and Method Validation
}

\author{
Marlice A. S. Marques, Henrique M. G. Pereira* and Francisco R. de Aquino Neto \\ Instituto de Química, Universidade Federal do Rio de Janeiro, Ilha do Fundão, CT Bloco A, \\ 21949-900 Rio de Janeiro-RJ, Brazil
}

\begin{abstract}
Um procedimento é descrito para a determinação simultânea de substâncias androgênicas, incluindo esteróides e $\beta_{2}$-agonistas. O método envolve a análise de compostos anabólicos em urina hidrolisada, usando-se extração líquido-líquido com subseqüente conversão a derivados trimetilsililéteres, para análise por CG-EM. Injeção com divisão de fluxo de 1/10 dos derivados TMS a $280{ }^{\circ} \mathrm{C}$, em uma coluna capilar, inicialmente mantida a $140{ }^{\circ} \mathrm{C}$ e então programada para $180{ }^{\circ} \mathrm{C}$ a $40{ }^{\circ} \mathrm{C} \mathrm{min}{ }^{-1}$, seguida por $3{ }^{\circ} \mathrm{C} \min ^{-1}$ até $230{ }^{\circ} \mathrm{C}$, e então, $40{ }^{\circ} \mathrm{C} \mathrm{min}{ }^{-1}$ até $300{ }^{\circ} \mathrm{C}$, resulta em uma boa resolução e formato de pico para todos os compostos. Os limites de detecção da maioria dos esteróides foi de $1 \mathrm{ng} \mathrm{mL} L^{-1}$, exceto para a formebolona e trembolona $\left(25 \mathrm{ng} \mathrm{mL}^{-1}\right)$. Quando aplicado a amostras de urinas selecionadas com evidência de degradação bacteriana e metabólitos provenientes de medicação/vitaminas, o método permite a rápida triagem para androgênios e outras substâncias monitoradas em rotina. A resolução foi adequada para avaliar o perfil esteroidal endógeno, relevante para controle de dopagem e aplicações médicas.
\end{abstract}

A procedure is described for the simultaneous determination of androgenic substances including steroids and $\beta_{2}$-agonists. The method involves analysis of hydrolized urinary anabolic compounds using liquid-liquid extraction, with subsequent conversion to trimethylsilylether derivatives for the analysis by GC-MS. Pulse split injection $1 / 10$ of the TMS derivatives at $280{ }^{\circ} \mathrm{C}$ into the capillary column, initially maintained at $140{ }^{\circ} \mathrm{C}$ then programmed to $180{ }^{\circ} \mathrm{C}$ at $40{ }^{\circ} \mathrm{C} \mathrm{min}{ }^{-1}$, followed by $3{ }^{\circ} \mathrm{C}$ $\mathrm{min}^{-1}$ to $230{ }^{\circ} \mathrm{C}$ and then $40{ }^{\circ} \mathrm{C} \mathrm{min}^{-1}$ to $300{ }^{\circ} \mathrm{C}$, resulted in good resolution and peak shape for all compounds. The detection limits of most of the steroids were $1 \mathrm{ng} \mathrm{mL}^{-1}$ except for formebolone and trenbolone $\left(25 \mathrm{ng} \mathrm{mL}^{-1}\right)$. When applied to selected urine samples with evidence of bacterial degradation and metabolites from usual medications/vitamins, the method allowed rapid screening for androgens and other substances monitored in routine. The resolution was adequate to evaluate the endogenous steroid profile relevant to doping control and medical applications.

Keywords: steroids, anabolic, doping control, gas chromatography, mass spectrometry

\section{Introduction}

The simultaneous detection and identification of various androgens is a commonly encountered problem in clinical androgen assays and metabolic studies as well as in doping control of anabolic agents. ${ }^{1-10}$ A prerequisite for the identification and quantitation of anabolic exogenous and endogenous steroids by gas chromatography-mass spectrometry (GC-MS) is an efficient derivatization procedure and a high signal-to-noise ratio $(\mathrm{S} / \mathrm{N})$ for their chromatographic peaks. ${ }^{11,12}$ With the advent of new drugs used by athletes, different classes of substances with unequal pharmacologic properties, but similar physicochemistry

* e-mail: henriquemarcelo@iq.ufrj.br ones, as the steroids and $\beta_{2}$-agonists, were included in the screening procedure for anabolic compounds, with the aim to decrease cost-effectiveness in doping control. Most of them elutes at the beginning of the chromatogram. Therefore changes in the traditional GC-MS parameters adopted by most World Anti-Doping Agency (WADA) accredited laboratories need an exhaustive study to prove that the new conditions are efficient and the method is robust. ${ }^{13}$ Therefore any improvement should be checked not only with normal urine, but using also different sources of urine, that contain coeluting compounds leading to assimetrical chromatographic signals and impure mass spectra of the substances of interest. ${ }^{13-19}$ Previous results demonstrated that it was advantageous to change the traditional column temperature program. ${ }^{13}$ 
Using $140{ }^{\circ} \mathrm{C}$ as initial oven temperature it was possible to obtain narrower initial analyte distributions for the compounds that elutes at the beginning of the chromatogram such as clenbuterol, mabuterol, epimethendiol (EMD) and norandrosterone, without loss of derivatized metabolites signal. Late eluting analytes, as the stanozolol metabolites, furazabol and oxandrolone were not affected. ${ }^{13}$ Further focusing of early eluting peaks by initial temperatures below $140{ }^{\circ} \mathrm{C}$, resulted in incomplete derivatization for some analytes mainly stanozolol related structures. Therefore evaluation of derivatization conditions as occurring in three steps, the vial, vaporization chamber and capillary column, was thoroughly assessed. ${ }^{13}$ The new program temperature improves the signal/noise ratio for some compounds and show adequate resolution for endogenous compounds. All of the difficult key separations necessary for doping control enforcement were also obtained with the proposed method. In extension of chromatografic studies and doping control of anabolic agents, the present study was undertaken to investigate the optimum conditions of GC-MS with selectedion-monitoring (SIM) acquisition mode for screening most common androgens as their trimethylsilyl (TMS) derivatives using a pool of selected urine samples to test the robustness of the method in extreme conditions. Selected steroids and non-steroidal substances and urines with different physicochemical properties, such as $\mathrm{pH}(5-9.0)$, density (1.000-1.037) and bacterially degraded, were selected to test the resolution of key endogenous steroids, absence of interference from drugs and vitamins and the robustness of the new analytical GC-MS conditions reported early. ${ }^{13}$

\section{Experimental}

\section{Reagents, chemicals and solutions}

The following substances: Stanozolol, 3'OH-stanozolol, mabuterol, clenbuterol, norandrosterone, epimethendiol, $16 \beta$ OH-furazabol (main metabolite, M1), oxandrolone, methyltestostrone metabolites (M1 and M2) and the other steroids were a kind gift from Dr. W. Schänzer and H. Geyer from the Institute of Biochemistry, Germany Sports University, Cologne, Germany. Methyltestosterone as an internal standard was bought from Aldrich (Milwaukee, WI, USA). All reagents were analytical grade. $N$-methyl- $N$-(trimethylsilyl)-trifluoroacetamide (MSTFA) was purchased from Chem Fabrik (Waldstetten, Germany). $\mathrm{NH}_{4} \mathrm{I}$ and ethanethiol from Sigma (St. Louis, MO, USA). Methanol from Tedia (Fairfield, USA). Stock solutions were prepared in methanol at a concentration of $1000 \mathrm{ng} \mu \mathrm{L}^{-1}$. These solutions were further diluted to yield appropriate working solutions for the preparation of the calibration standard. The solutions were sealed and frozen at $-20{ }^{\circ} \mathrm{C}$ until use. Methyltestosterone was used as an internal standard (ISTD).

\section{Equipment and conditions}

Hewlett Packard (Palo Alto, CA, USA) gas chromatograph (6890 series) equipped with a $7673 \mathrm{HP}$ auto sampler coupled with a quadrupole mass spectrometer (MS), Agilent (MS 5973 Network). Carrier gas was Helium $1 \mathrm{~mL} \mathrm{~min}$ m $^{-1}$ HP-1 capillary column (100\% methylsiloxane, $17 \mathrm{~m}$, $0.20 \mathrm{~mm}$ I.D., film thickness $0.11 \mu \mathrm{m})$. Injector temperature was $280^{\circ} \mathrm{C}$. Injection mode: split $1 / 10$, pulse pressure 50 psi / 0.80 min. Injection volumes of $3 \mu \mathrm{L}$; constant flow 1 $\mathrm{mL} \mathrm{min}^{-1}$. The GC temperature programming rates were as follows: initial column oven temperature $140{ }^{\circ} \mathrm{C}$ then programmed to rise to $180{ }^{\circ} \mathrm{C}$ at $40^{\circ} \mathrm{C} \mathrm{min}^{-1}$, then to $240{ }^{\circ} \mathrm{C}$ at $3{ }^{\circ} \mathrm{C} \mathrm{min}{ }^{-1}$ and to $300{ }^{\circ} \mathrm{C}$ at $40{ }^{\circ} \mathrm{C} \mathrm{min}^{-1}$ (held $3 \mathrm{~min}$ ). The transfer line was at $280{ }^{\circ} \mathrm{C}$. A split/splitless in house deactivated $^{13}$ glass single-taper liner from HP (79 mm x 7 mm I.D.) (cup $6 \mathrm{~mm}$ length $\mathrm{x} 1 \mathrm{~mm}$ hole) and an internal volume of $0.9 \mathrm{~mL}$ was used. Inside the liner, $0.017 \mathrm{mg}$ of deactivated glass wool were well compacted between 23 and $33 \mathrm{~mm}$ measured from its top. Mass spectrometer operating conditions: ion source temperature $220{ }^{\circ} \mathrm{C}$; interface temperature, $280{ }^{\circ} \mathrm{C}$; quadrupole temperature, 150 ${ }^{\circ} \mathrm{C}$; accelerating voltage, $200 \mathrm{eV}$ higher than the manual tune; and ionization voltage, $70 \mathrm{eV}$. Mass spectra was obtained in SIM mode, triple ion monitoring for each analyte was performed. The dwell time was $20 \mathrm{~ms}$ for the analytes and $20 \mathrm{~ms}$ for the internal standard ions.

\section{Sample preparation}

All urine samples obtained from male athletes were individually processed in our routine screening for androgen analysis. Isolation of androgens was based on liquid-liquid extraction procedure that is well established for steroid profiling in doping control. ${ }^{14}$ Briefly, 0.750 $\mathrm{mL}$ of $0.8 \mathrm{~mol} \mathrm{~L}^{-1}$ sodium phosphate buffer $\mathrm{pH} 7.0$ are added to $2 \mathrm{~mL}$ of urine. To the buffer solution $25 \mu \mathrm{L}$ of ISTD and $50 \mu \mathrm{L}$ of $\beta$-glucuronidase from $E$. Coli are added and the hydrolysis performed for $1 \mathrm{~h}$ at $50{ }^{\circ} \mathrm{C}$. The buffered solution is alkalinized with $500 \mu \mathrm{L}$ of $20 \%$ potassium carbonate solution to $\mathrm{pH} 9.0$ and the analytes extracted with $5 \mathrm{~mL}$ of t-butylmethyl ether (TBME). The tubes were capped and shaken vigorously for $5 \mathrm{~min}$ and centrifuged at $3000 \mathrm{rpm}$ for $5 \mathrm{~min}$. The organic phase was transferred to another screw-cap glass $(100 \mathrm{~mm} \times 16 \mathrm{~mm})$ tube and evaporated to dryness under nitrogen at $40{ }^{\circ} \mathrm{C}$. The residues were dried in a desiccator over $\mathrm{P}_{2} \mathrm{O}_{5} / \mathrm{KOH}$ for at least 40 min before derivatization. 


\section{Derivatization prior to $G C-M S$ analysis}

Previously to GC-MS analysis, N,O-TMS and O-TMS derivatives were formed. The dried residues were kept inside desiccators containing $\mathrm{P}_{2} \mathrm{O}_{5} / \mathrm{KOH}$ during 20 min. The residue was then dissolved in $100 \mu \mathrm{L}$ of MSTFA$\mathrm{NH}_{4}$ I-ethanethiol $(1000: 2: 6, \mathrm{v} / \mathrm{m} / \mathrm{v})$ and heated at $60{ }^{\circ} \mathrm{C}$. Three micro liters of each sample were injected into the GC-MS system.

\section{Data processing}

Calculations for the determination of the validation parameters were performed using in-house spreadsheets programmed in Excell linked to SPSS for windows. ${ }^{15-20}$ These spreadsheets perform the analysis of variance Tables for the determination of precision, accuracy, goodness of fit, calculate the detection and determination limits, lack of fit, freeze/thaw stability.

Calibration graphics were calculated by weighed linear regression $(\mathrm{W}=1 / \mathrm{X})$ analysis on the responses (ratio of the area of analyte over the area of ISTD) of a series of calibration samples versus the corresponding nominal concentrations.

\section{Validation of the analytical procedure}

To validate the present method a full pre-study validation routine has been performed, including sensitivity, specificity, linearity, accuracy, precison and reproducibility. ${ }^{15-20}$

\section{Assay validation}

The calibration curves consisted of five concentrations $\left(2.0,4.0,6.0,8.0\right.$ and $\left.10.0 \mathrm{ng} \mathrm{mL}^{-1}\right)$ of analyte per $2 \mathrm{~mL}$ human urine. Each concentration point was determined in five replicates. These curves were prepared by adding internal standard $\left(10.0 \mathrm{ng} \mathrm{mL}^{-1}\right)$ and varying concentrations of authentic analytes to human urine obtained from routine screening. The ratios of the peak area of $\mathrm{m} / \mathrm{z}$ monitored for analyte over the peak area of $m / z 446$ (ISTD) were calculated and plotted against the concentrations of analyte added. Linearity was determined by weighed linear regression model $(\mathrm{W}=1 / \mathrm{X})$.

Precision and accuracy of the method were evaluated intra- and inter-day by analysis of five replicates of quality control samples for each of three concentrations including the Limit of Quantification (LOQ) and quality control concentrations $\left(2.4,4.0\right.$ and $\left.9.0 \mathrm{ng} \mathrm{mL}^{-1}\right)$, against a calibration curve. The accuracy of the method was determined as percent error [(difference between the mean calculated and added concentration) / added concentration] $\mathrm{x} 100$, while precision was evaluated by intra-day and inter-day coefficients of variations.

The recovery of the analytes was determined by comparison of peak areas from urine samples spiked with known amounts of each drug (2.0, 6.0 and $\left.10.0 \mathrm{ng} \mathrm{mL}^{-1}\right)$, processed according to the described method versus nonextracted pure standards. Each concentration of urine samples was prepared in five replicates. Specificity in relation to endogenous urine components was demonstrated by analysis of a series of randomly selected blank urine samples $(n=12)$.

\section{Stability studies}

Stability of analytes in urine was studied at room temperature and $-20{ }^{\circ} \mathrm{C}$. Control human urine samples were spiked with 2.4, 4.0 and $9.0 \mathrm{ng} \mathrm{mL}^{-1}$ of analyte. Each determination was performed in triplicate. Spiked urines were analyzed immediately after preparation and after repeated freeze $\left(-20^{\circ} \mathrm{C}\right)$ thaw $\left(\sim 25^{\circ} \mathrm{C}\right)$ cycles on three consecutive days.

\section{Autosampler stability}

To evaluate autosampler stability, three aliquots of each sample type were mantained, immediately after preparation, at the autosampler temperature used during analysis, for the anticipated time the batch size would take to run. Therefore, the parameters were: autosampler temperature $22{ }^{\circ} \mathrm{C}$. Anticipated batch run time, 24 hours, and test timed 34 hours. The stability of the analyte and the internal standard was checked against the same samples injected immediately after preparation.

\section{Stock solution stability}

To evaluate the stock solution stability, each analyte and internal standard stock solution was prepared freshly and compared to the same stock solution after freezing for 1 year.

\section{Screening of male urine with special characteristics}

Urine with high density, high $\mathrm{pH}$ and showing extensive bacteria degradation profile or presence of some key medicines, selected after convencional screening procedures, were submitted to GC-MS analysis using the new GC-MS conditions reported herein, to evaluate the robustness of the method. ${ }^{21-28}$ 


\section{Results and Discussion}

\section{Chromatography and specificity}

Representative chromatograms of SIM analysis of the samples spiked with analytes and internal standard and of the urine blank shown that there are no chromatographic peaks interfering with the analytes or internal standard. With the sample processing and chromatographic conditions described, analytes and internal standard were well resolved from each other.

\section{Linearity}

The calibration curves were prepared over the concentration range of 2.0 to $10.0 \mathrm{ng} \mathrm{mL}^{-1}$ of analytes in human urine. Regression analysis of the correlation between the chromatographic peak area ratios of analyte/ internal standard versus known concentrations of analytes yielded linear correlation over the concentration range analyzed. The corresponding mean \pm standard deviation (S.D.), determination coefficients $\left(\mathrm{r}^{2}\right)$ and coefficients from the calibration curve (slope and intercept) for the curves prepared on different days $(n=4)$ were sumarized in Table 1 for main compounds. The goodness of fit was evaluated by means of analysis of variance $\left(\mathrm{F}_{\text {test }}, \alpha=0.05\right),{ }^{15-20}$ the $\mathrm{F}_{\text {table }}$ were higher than $\mathrm{F}_{\text {calculated }}$ for all calibration curves.

Inter-assay reproducibility was determined for calibration curves prepared on four different days, and the average results are given in Table 1 . For concentration of calibration standards ranging from 2.0 to $10.0 \mathrm{ng} \mathrm{mL}$ 1 , the precision around the mean value have not exceeded $15 \%$ coefficients of variation (Table 1 ).

\section{Precision and accuracy}

Intra-day and inter-day precision and accuracy of the method, assessed by analysing quality control samples (2.4, 4.0 and $9.0 \mathrm{ng} \mathrm{mL}^{-1}$ ), are given in Tables 2-4. The following validation criteria for precision and accuracy were used to assess the suitability of the method the precision determined at each concentration level should not exceed $15 \%$ coefficient of variation (CV) except at the limit of quantitation where it should not exceed $20 \% \mathrm{CV} ;{ }^{15-20}$ accuracy should be within 10 to $15 \%$ except at the limit of quantitation where it should be within 15 to $20 \% .^{14-19}$ As shown in Tables 2-4, the intraday precision was between 1.6 and $12.4 \%$ over the $2.4-9.0$ $\mathrm{ng} \mathrm{mL}^{-1}$ concentration range of analytes, and the corresponding accuracy varied from 3.0 to $17.2 \%$. The inter-day precision was between 1.0 and $10.8 \%$ over the $2.4-9.0 \mathrm{ng}$ $\mathrm{mL}^{-1}$ concentration range of analytes, and the corresponding accuracy varied from 3.3 to $12.9 \%$. The results show that the method has good reproducibility and accuracy. The precision and accuracy at the three concentrations (2.4, 4.0 and 9.0 ng $\mathrm{mL}^{-1}$ ) were acceptable in view of the mentioned above international recommendations.

\section{Recovery}

The mean recoveries of analytes in urine samples after extraction and derivatization procedures are summarized on Table 5. The value was higher than 91.2 for the analytes. Mean of internal standard was $94.1 \pm$ $2.5 \%\left(10.0 \mathrm{ng} \mathrm{mL}^{-1}, \mathrm{n}=15\right)$.

\section{Limit of quantitation and limit of detection}

The criteria for the determination of the limit of quantitation of analytes in urine was based on a $\mathrm{S} / \mathrm{N}$ ratio at least five times greater than any interference in blanks at the retention time of the analyte. The limit of detection (LOD) and quantitation of the analytes are shown in Table 5. The LOD range from 0.6 to 1.5 for compounds evaluated, at a S/N of 3 .

\section{Stability studies}

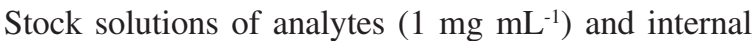
standard $\left(1 \mathrm{mg} \mathrm{mL}^{-1}\right)$ were stable at $-20{ }^{\circ} \mathrm{C}$ for at least one year, with exception of oxandrolone and epioxandrolone. ${ }^{29}$

Table 1. Inter-day reproducibility of the standard curve obtained for the analysis of clenbuterol, EMD, norandrosterone, 3'OH-stanozolol, methyltestosterone-M1 and M2 in urine

\begin{tabular}{lcccc}
\hline Substance & $\mathrm{r}^{2}$ & C.V. $(\%)$ & $\mathrm{a}$ & $\mathrm{b}$ \\
\hline Clenbuterol & $0.996 \pm 0.000$ & 0.0571 & $0.279 \pm 0.00$ & $-0.039 \pm 14.33$ \\
Norandrosterone & $0.995 \pm 0.032$ & 0.3232 & $0.021 \pm 14.50$ & $0.113 \pm 9.72$ \\
EMD & $0.992 \pm 0.002$ & 0.2291 & $0.090 \pm 10.10$ & $0.034 \pm 8.11$ \\
Methyltestosterone-M1 & $0.997 \pm 0.002$ & 0.2000 & $0.650 \pm 10.00$ & $1.480 \pm 7.00$ \\
Methyltestosterone-M2 & $0.995 \pm 0.002$ & 0.2000 & $0.010 \pm 14.00$ & $0.113 \pm 9.72$ \\
3'OH-Stanozolol & $0.992 \pm 0.003$ & 0.2677 & $0.012 \pm 14.50$ & $0.233 \pm 18.94$
\end{tabular}

${ }^{\mathrm{a}}$ Slope; ${ }^{\mathrm{b}} \mathrm{Y}$ intercept and the uncertainties (\%). 
Table 2. Intra- and inter-day accuracy, precision for the QC samples for norandrosterone and EMD

\begin{tabular}{|c|c|c|c|}
\hline $\begin{array}{l}\text { Urine concentration } \\
\left(\mathrm{ng} \mathrm{mL}^{-1}\right)\end{array}$ & $\begin{array}{l}\text { Concentration calculated } \\
(\text { mean } \pm \text { S.D. })\left(\mathrm{ng} \mathrm{mL}^{-1}\right)\end{array}$ & C.V. $(\%)^{\mathrm{a}}$ & $\operatorname{Bias}(\%)^{\mathrm{b}}$ \\
\hline \multicolumn{4}{|l|}{ Norandrosterone } \\
\hline \multicolumn{4}{|c|}{ Intra-day reproducibility $(n=3)$} \\
\hline 2.4 & $2.8 \pm 0.2$ & 5.5 & 17.2 \\
\hline 4.0 & $4.2 \pm 0.2$ & 5.1 & 5.1 \\
\hline 9.0 & $9.3 \pm 1.0$ & 11.1 & 7.6 \\
\hline \multicolumn{4}{|c|}{ Inter-day reproducibility $(\mathrm{n}=9)$} \\
\hline 2.4 & $2.7 \pm 0.1$ & 4.6 & 10.2 \\
\hline 4.0 & $4.0 \pm 0.2$ & 4.5 & 4.1 \\
\hline 9.0 & $9.2 \pm 0.1$ & 1.5 & 4.4 \\
\hline \multicolumn{4}{|l|}{$E M D$} \\
\hline \multicolumn{4}{|c|}{ Intra-day reproducibility $(\mathrm{n}=3)$} \\
\hline 2.4 & $2.6 \pm 0.2$ & 6.3 & 7.3 \\
\hline 4.0 & $4.4 \pm 0.2$ & 5.1 & 9.3 \\
\hline 9.0 & $9.3 \pm 0.2$ & 1.8 & 3.0 \\
\hline \multicolumn{4}{|c|}{ Inter-day reproducibility $(\mathrm{n}=9)$} \\
\hline 2.4 & $2.6 \pm 0.1$ & 3.0 & 8.1 \\
\hline 4.0 & $4.3 \pm 0.1$ & 1.7 & 9.5 \\
\hline 9.0 & $9.2 \pm 0.2$ & 1.7 & 3.3 \\
\hline
\end{tabular}

a Coefficient of variation (CV): is a measure of relative dispersion equal to the ratio of standard deviation to mean. In practice "scales" the standard deviation (s) by the size of the mean $(\mathrm{X}) .[\mathrm{CV}=100 \mathrm{x}(\mathrm{s} / \mathrm{X})] .{ }^{\mathrm{b}}$ Bias: A statistical testing error caused by systematically favoring some outcomes over others.

Table 3. Intra- and inter-day accuracy, precision, and uncertainty for the QC samples for methyltestosterone-M1 and M2

\begin{tabular}{|c|c|c|c|}
\hline $\begin{array}{l}\text { Urine concentration } \\
\left(\mathrm{ng} \mathrm{mL} \mathrm{L}^{-1}\right)\end{array}$ & $\begin{array}{l}\text { Concentration calculated } \\
(\text { mean } \pm \text { S.D. })\left(\mathrm{ng} \mathrm{mL}^{-1}\right)\end{array}$ & C.V. $(\%)^{\mathrm{a}}$ & $\operatorname{Bias}(\%)^{\mathrm{b}}$ \\
\hline \multicolumn{4}{|l|}{ Methyltestosterone-M1 } \\
\hline \multicolumn{4}{|c|}{ Intra-day reproducibility $(\mathrm{n}=3)$} \\
\hline 2.4 & $2.6 \pm 0.2$ & 8.1 & 8.7 \\
\hline 4.0 & $4.1 \pm 0.3$ & 7.9 & 7.1 \\
\hline 9.0 & $9.4 \pm 0.9$ & 9.3 & 7.5 \\
\hline \multicolumn{4}{|c|}{ Inter-day reproducibility $(\mathrm{n}=9)$} \\
\hline 2.4 & $2.6 \pm 0.2$ & 7.1 & 5.9 \\
\hline 4.0 & $4.1 \pm 0.1$ & 3.3 & 8.2 \\
\hline 9.0 & $9.4 \pm 0.3$ & 3.1 & 6.0 \\
\hline \multicolumn{4}{|c|}{ Methyltestosterone-M2 } \\
\hline \multicolumn{4}{|c|}{ Intra-day reproducibility $(n=3)$} \\
\hline 2.4 & $2.7 \pm 0.0$ & 1.6 & 13.9 \\
\hline 4.0 & $4.0 \pm 0.2$ & 6.1 & 4.9 \\
\hline 9.0 & $9.2 \pm 0.8$ & 8.6 & 7.1 \\
\hline \multicolumn{4}{|c|}{ Inter-day reproducibility $(\mathrm{n}=9)$} \\
\hline 2.4 & $2.7 \pm 0.1$ & 2.7 & 9.7 \\
\hline 4.0 & $3.9 \pm 0.1$ & 2.3 & 3.4 \\
\hline 9.0 & $9.1 \pm 0.2$ & 2.5 & 5.9 \\
\hline
\end{tabular}

a Coefficient of variation $(\mathrm{CV})$ : is a measure of relative dispersion equal to the ratio of standard deviation to mean. In practice "scales" the standard deviation (s) by the size of the mean $(\mathrm{X}) .[\mathrm{CV}=100 \mathrm{x}(\mathrm{s} / \mathrm{X})]$. ${ }^{\mathrm{b}}$ Bias: A statistical testing error caused by systematically favoring some outcomes over others.

Stability of analytes in human urine was studied at three concentrations $\left(2.4,4.0\right.$ and $\left.9.0 \mathrm{ng} \mathrm{mL}^{-1}\right)$ and compared with data obtained from freshly prepared samples. Analytes were stable in human urine after at least three freeze-thaw cycles and the mean recoveries were higher than $95 \%$.

\section{Urine matrix analysis. The signal-to noise ratio}

The signal-to-noise ratios of [analytes $\mathrm{m} / \mathrm{z}$ diagnostic ion] / [ $\mathrm{m} / z 446$ (ISTD)] observed using new temperature program from the set used to estabilish the linearity of the method are presented in Table 6. The corresponding 
Table 4. Intra- and inter-day accuracy and precision for the QC samples for 3'OH-stanozolol and clenbuterol

\begin{tabular}{|c|c|c|c|}
\hline $\begin{array}{l}\text { Urine concentration } \\
\left(\mathrm{ng} \mathrm{mL} \mathrm{mL}^{-1}\right)\end{array}$ & $\begin{array}{l}\text { Concentration calculated } \\
(\text { mean } \pm \text { S.D. })\left(\mathrm{ng} \mathrm{mL}^{-1}\right)\end{array}$ & C.V. $(\%)^{\mathrm{a}}$ & $\operatorname{Bias}(\%)^{\mathrm{b}}$ \\
\hline \multicolumn{4}{|l|}{ 3'OH-stanozolol } \\
\hline \multicolumn{4}{|c|}{ Intra-day reproducibility $(\mathrm{n}=3)$} \\
\hline 2.4 & $2.8 \pm 0.3$ & 10.5 & 16.5 \\
\hline 4.0 & $4.3 \pm 0.2$ & 4.8 & 6.4 \\
\hline 9.0 & $9.0 \pm 0.8$ & 9.0 & 6.4 \\
\hline \multicolumn{4}{|c|}{ Inter-day reproducibility $(\mathrm{n}=9)$} \\
\hline 2.4 & $2.6 \pm 0.3$ & 10.8 & 12.9 \\
\hline 4.0 & $3.9 \pm 0.3$ & 7.5 & 6.9 \\
\hline 9.0 & $8.9 \pm 0.3$ & 3.8 & 4.8 \\
\hline \multicolumn{4}{|l|}{ Clenbuterol } \\
\hline \multicolumn{4}{|c|}{ Intra-day reproducibility $(\mathrm{n}=3)$} \\
\hline 2.4 & $2.4 \pm 0.3$ & 6.8 & 4.9 \\
\hline 4.0 & $4.1 \pm 0.4$ & 9.3 & 7.9 \\
\hline 9.0 & $9.1 \pm 0.7$ & 12.4 & 9.2 \\
\hline \multicolumn{4}{|c|}{ Inter-day reproducibility $(n=9)$} \\
\hline 2.4 & $2.5 \pm 0.5$ & 4.8 & 6.0 \\
\hline 4.0 & $4.1 \pm 0.7$ & 5.7 & 8.1 \\
\hline 9.0 & $9.0 \pm 0.0$ & 1.0 & 7.2 \\
\hline
\end{tabular}

${ }^{a}$ Coefficient of variation $(\mathrm{CV})$ : is a measure of relative dispersion equal to the ratio of standard deviation to mean. In practice "scales" the standard deviation (s) by the size of the mean $(\mathrm{X}) .[\mathrm{CV}=100 \mathrm{x}(\mathrm{s} / \mathrm{X})] .{ }^{\mathrm{b}}$ Bias: A statistical testing error caused by systematically favoring some outcomes over others.

Table 5. Limits of detection and quantitation, recovery and uncertainty for the QC samples for Clenbuterol, norandrosterone, EMD, MethyltestosteroneM1, Methyltestosterone-M2 and 3'OH-stanozolol

\begin{tabular}{|c|c|c|c|c|}
\hline \multirow[t]{2}{*}{ Substance } & \multicolumn{2}{|c|}{ Limits $\left(\mathrm{ng} \mathrm{mL}^{-1}\right)$} & \multirow[t]{2}{*}{ Recovery $^{\mathrm{a}}$} & \multirow{2}{*}{$\begin{array}{c}\text { Uncertainty } \\
\text { estimate }\end{array}$} \\
\hline & detection & quantification & & \\
\hline Clenbuterol & 0.69 & 2.10 & $92.9 \pm 6.9$ & 2.6 \\
\hline Norandrosterone & 0.63 & 1.69 & $104.1 \pm 5.7$ & 2.6 \\
\hline EMD & 0.51 & 1.50 & $101.6 \pm 12.4$ & 2.6 \\
\hline Methyltestosterone-M1 & 0.37 & 1.10 & $96.0 \pm 6.0$ & 2.6 \\
\hline Methyltestosterone-M2 & 0.29 & 0.90 & $94.2 \pm 6.2$ & 2.7 \\
\hline 3'OH-stanozolol & 0.18 & 0.60 & $91.2 \pm 8.6$ & 2.6 \\
\hline
\end{tabular}

${ }^{\mathrm{a}}$ The recovery was calculated in three concentrations $\left(2,6\right.$ and $\left.10 \mathrm{ng} \mathrm{mL} \mathrm{mL}^{-1}\right)$.

Table 6. (S/N) ratio of methyltestosterone-M1, methyltestosterone-M2, 3'OH-stanozolol, norandrosterone, EMD and clenbuterol observed using new temperature program in $2 \mathrm{ng} \mathrm{mL}^{-1}$ concentration level. Linearity estimated in concentrations levels $2,4,6,8$ and $10 \mathrm{ng} \mathrm{mL}^{-1}$

\begin{tabular}{llc}
\hline Substance & Linearity estimated & $\begin{array}{r}(\mathrm{S} / \mathrm{N}) \text { ration in } \\
2 \mathrm{ng} \mathrm{mL}^{-1}\end{array}$ \\
\hline Methyltestosterone-M1 & $\begin{array}{l}\mathrm{y}=15.08 \mathrm{x}+7.96 \\
\mathrm{r}^{2}=0.9941\end{array}$ & 38 \\
Methyltestosterone-M2 & $\begin{array}{l}\mathrm{y}=17.74 \mathrm{x}-1.135 \\
\mathrm{r}^{2}=0.9868\end{array}$ & 34 \\
3'OH-stanozolol & $\mathrm{y}=15.16 \mathrm{x}-6.54$ & 23 \\
Norandrosterone & $\mathrm{r}^{2}=0.9803$ & \\
EMD & $\begin{array}{l}\mathrm{y}=19.59 \mathrm{x}-27.16 \\
\mathrm{r}^{2}=0.9935\end{array}$ & \\
Clenbuterol & $\mathrm{y}=13.75 \mathrm{x}+33.65$ & 61 \\
& $\mathrm{r}^{2}=0.9876$ & \\
& $\mathrm{y}=8.52 \mathrm{x}+22.17$ & 42 \\
$\mathrm{r}^{2}=0.9941$ & \\
\hline
\end{tabular}

determination coefficients $\left(\mathrm{r}^{2}\right)$ for the curves are higher than 0.99 . The $\mathrm{CV}$ for $\mathrm{S} / \mathrm{N}$ values were $<20 \%$.

Urine matrix caused problems with both temperature programs (traditional and new temperature program) for compounds that eluted after 8 minutes at trace concentration of $2.0 \mathrm{ng} \mathrm{mL}^{-1} \cdot{ }^{13}$ But for compounds that eluted at the beginning of chromatogram such as clenbuterol, mabuterol, terbutaline, the $\mathrm{S} / \mathrm{N}$ ratios were higher at the new conditions adopted than using higher initial oven temperatue as in the traditional program. The $\mathrm{S} / \mathrm{N}$ ratios observed at $140{ }^{\circ} \mathrm{C}$ initial oven temperature were 27, 42 for mabuterol and clenbuterol, respectively and using the classical initial oven temperature of $180^{\circ} \mathrm{C}$ the signal/noise ratio for the same compounds were 4 and 7 . 
Table 7. Parameters of the steroid profile, which make a urine sample suspicious for an application of exogenous DHT endogenous application ${ }^{9}$

\begin{tabular}{lll}
\hline Parameter & men & women \\
\hline DHT & $>20.0 \mathrm{ng} \mathrm{mL}^{-1}$ & $>18.0 \mathrm{ng} \mathrm{mL}^{-1}$ \\
$\mathrm{~A} / \mathrm{E}$ & $>2.9$ & $>2.1$ \\
$5 \alpha, 3 \alpha$-DIOL/5 $\beta, 3 \alpha$-DIOL & $>1.5$ & $>1.3$ \\
DHT/E & $>8.2$ & $>8.5$ \\
DHT/EpiT & $>0.73$ & $>2.3$ \\
\hline
\end{tabular}

Concentration of DHT = dihydrotestosterone, $\mathrm{A}=$ androsterone, $\mathrm{E}=$ etiocholanolone, EpiT= epitestosterone , DIOL = androstanodiol.

Table 8. Comparison of the resolution obtained for key compounds for some peculiar urines, in relation to experiment $1\left[\mathrm{~T}_{\text {icolumn }}=180{ }^{\circ} \mathrm{C}\right]$ and experiment $2\left[\mathrm{~T}_{\text {icolumn }}=140{ }^{\circ} \mathrm{C}\right]^{13}$

\begin{tabular}{|c|c|c|}
\hline \multirow[t]{2}{*}{ Substance } & \multicolumn{2}{|c|}{ Resolution } \\
\hline & Experiment 1 & Experiment 2 \\
\hline \multicolumn{3}{|l|}{ Androsterone } \\
\hline Etiocholanolone & 1.79 & 2.01 \\
\hline \multicolumn{3}{|l|}{$5 \alpha, 3 \alpha-\mathrm{DIOL}$} \\
\hline $5 \beta, 3 \alpha-\mathrm{DIOL}$ & 1.43 & 1.60 \\
\hline \multicolumn{3}{|l|}{ OHA } \\
\hline $\mathrm{OHE}$ & 2.35 & 2.28 \\
\hline \multicolumn{3}{|l|}{ Dehydroepiandrosterone } \\
\hline Epiandrosterone & 0.87 & 0.95 \\
\hline \multicolumn{3}{|l|}{ Epitestosterone } \\
\hline Methylltestosterone-M2 & 0.08 & 0.09 \\
\hline \multicolumn{3}{|l|}{$\mathrm{OHE}$} \\
\hline Noretandrolone & 1.81 & 2.88 \\
\hline \multicolumn{3}{|l|}{ OHA } \\
\hline Testosterone & 3.22 & 3.44 \\
\hline \multicolumn{3}{|l|}{ Testosterone } \\
\hline Epioxandrolone & 0.44 & 0.69 \\
\hline \multicolumn{3}{|l|}{ Testosterone } \\
\hline Androstenedione & 2.94 & 3.19 \\
\hline \multicolumn{3}{|l|}{ Metenolone } \\
\hline Dehydroepiandrosterone & 1.27 & 1.47 \\
\hline \multicolumn{3}{|l|}{ Methyltestosterone-M1 } \\
\hline Methyltestosterone-M2 & 1.30 & 1.31 \\
\hline \multicolumn{3}{|l|}{ OHA } \\
\hline Bolasterone & 1.05 & 2.00 \\
\hline \multicolumn{3}{|l|}{ Norandrosterone } \\
\hline EMD & 2.89 & 3.16 \\
\hline \multicolumn{3}{|l|}{$\mathrm{TBOH}$} \\
\hline Epitestosterone & 1.62 & 1.63 \\
\hline \multicolumn{3}{|l|}{ Boldenone-M1 } \\
\hline EMD & 0.27 & 0.31 \\
\hline \multicolumn{3}{|l|}{ Mesterolone } \\
\hline Epitestosterone & 1.97 & 1.81 \\
\hline \multicolumn{3}{|l|}{ Metenolone } \\
\hline Mesterolone & 3.95 & 4.05 \\
\hline \multicolumn{3}{|l|}{ Dehydroepiandrosterone } \\
\hline Mesterolone & 2.19 & 2.69 \\
\hline
\end{tabular}

DHEA $=$ dehydroepiandrosterone; EMD = epimetendiol; $5 \alpha, 3 \alpha$ $\mathrm{DIOL}=5 \alpha$-androstane- $3 \alpha, 17 \beta$-diol; $5 \beta, 3 \alpha$-DIOL $=5 \beta$-androstane$3 \alpha, 17 \beta$-diol; $\mathrm{OHA}=11 \beta$-hydroxy-androsterone; $\mathrm{OHE}=11 \beta$-hydroxyetiocholanolone. $\mathrm{TBOH}=$ hidroxitrembolone.
Resolution of the main endogenous steroids

Several studies have shown that the steroid profile parameters, especially the steroid ratios could be used for confirmation of steroid misuse. ${ }^{9,30}$ Therefore they have to be taken into account when steroid profiles are interpreted. The principal parameter used to detect the misuse of testosterone precursor and also testosterone is the testosterone/epitestosterone (T/Epit) ratio. For $5 \alpha$ dihydrotestosterone (DHT) Geyer et al. ${ }^{9}$ have reported some steroid parameters that make a sample suspicious for exogenous application (Table 7).

Recently Catlin et al..$^{32}$ described that $6 \alpha-\mathrm{OH}-$ androstenediol and the ratio between the epitestosterone precursors, $5 \alpha$-androstane- $3 \alpha, 17 \beta$-diol ( $5 \alpha, 3 \alpha$-DIOL) and $5 \beta$-androstane- $3 \alpha, 17 \beta$-diol ( $5 \beta, 3 \alpha$-DIOL), could become a parameter for exogenous administration of androstenedione. Therefore some compounds have to be separated from their isomers and other endogenous substances to obtain a correct ratio and concentration. The first step in this study was to evaluate the separation of these analytes (Table 8 and Figure 1).

The second step, is to evaluate if the ratio between the main endogenous compounds is acceptable during screening of different batches (Figure 2a-b). In screening, $\mathrm{T} /$ Epit ratio and the estimation of the concentration of the analytes of interest is performed using the response factor obtained with a single calibration sample (QCT) at a ratio of 6 . To measure T/EpiT the quality control was analyzed $(n=41)$, during two months. It's Shewhart's control chart showed all points within the quality $\pm 2 \mathrm{STD}$, better than the criteria set as $\pm 3 \mathrm{STD}$ (Figure 2a). The same behaviour was observed for androsterone/etiocolanolone (A/E) (Figure $2 \mathrm{~b}, \mathrm{n}=20)$ and also for $5 \alpha$-androstan-3,17-dione $/ 5 \beta$ androstan-3,17-dione ( $3 \alpha, 5 \alpha$-DIOL / $3 \alpha, 5 \beta$-DIOL) and $11 \beta$-hydroxy-androsterone/ $11 \beta$-hydroxy-etiocholanolone (OHA/OHE) in the endogenous quality control (STDALL) monitored during one month.

\section{Separation of bacterial degradation products and analytes}

Potential degradation of steroids by microorganisms demonstrated by in vitro and in vivo observations has been a matter of concern for laboratories involved in doping control. ${ }^{27,28}$ Most studies have identified markers of bacterial metabolic activity on urinary excreted steroids in free form (unconjugated), such as $5 \alpha$-androstan-3,17dione, $5 \beta$-androstan-3,17-dione, and androstenedione. Urinary concentrations of these substances, which are usually present at very low levels, may increase very rapidly in contaminated urine..$^{27,28}$ 
a)
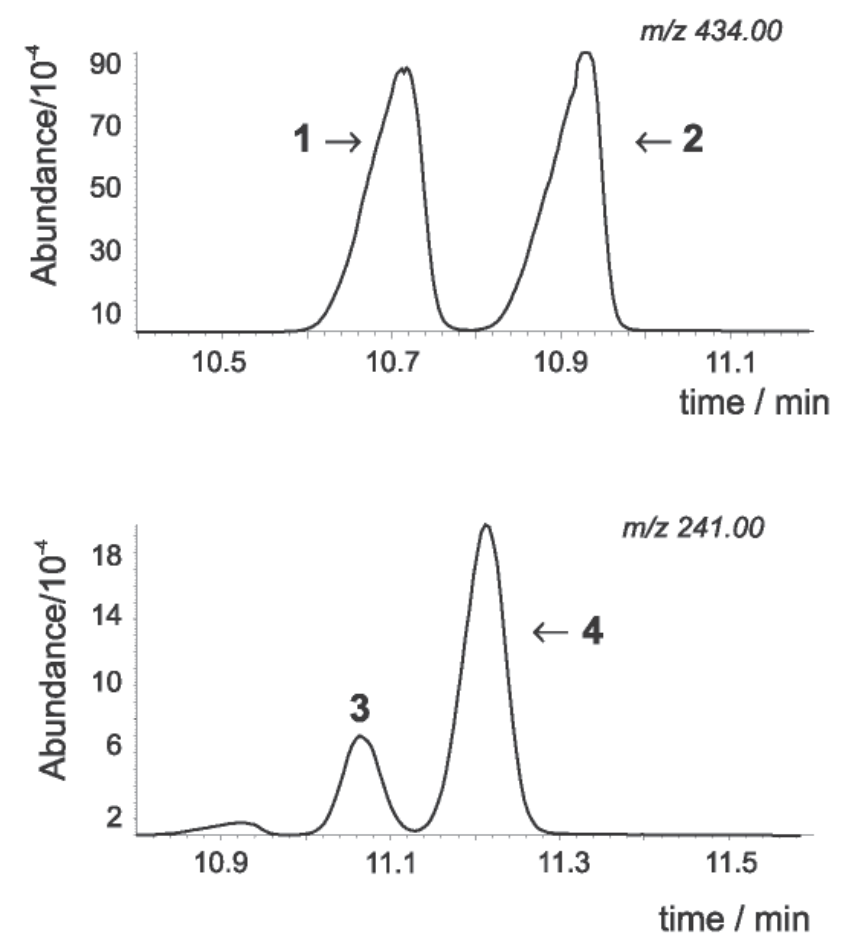

$\mathrm{m} / \mathrm{z} 522.00$

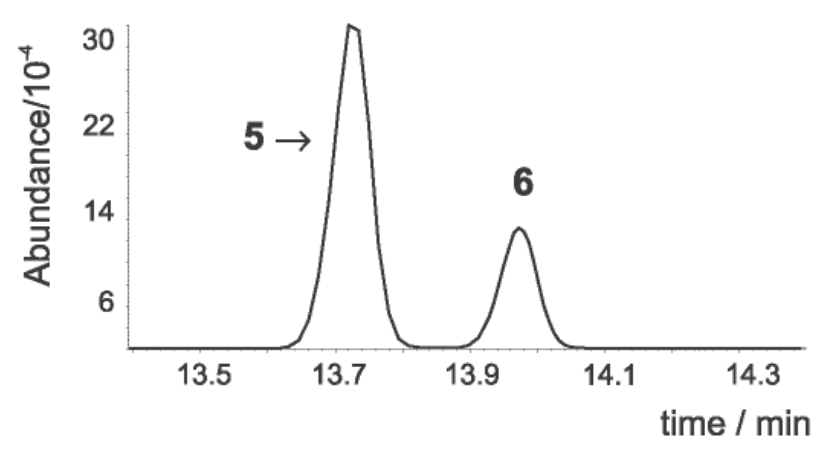

b)
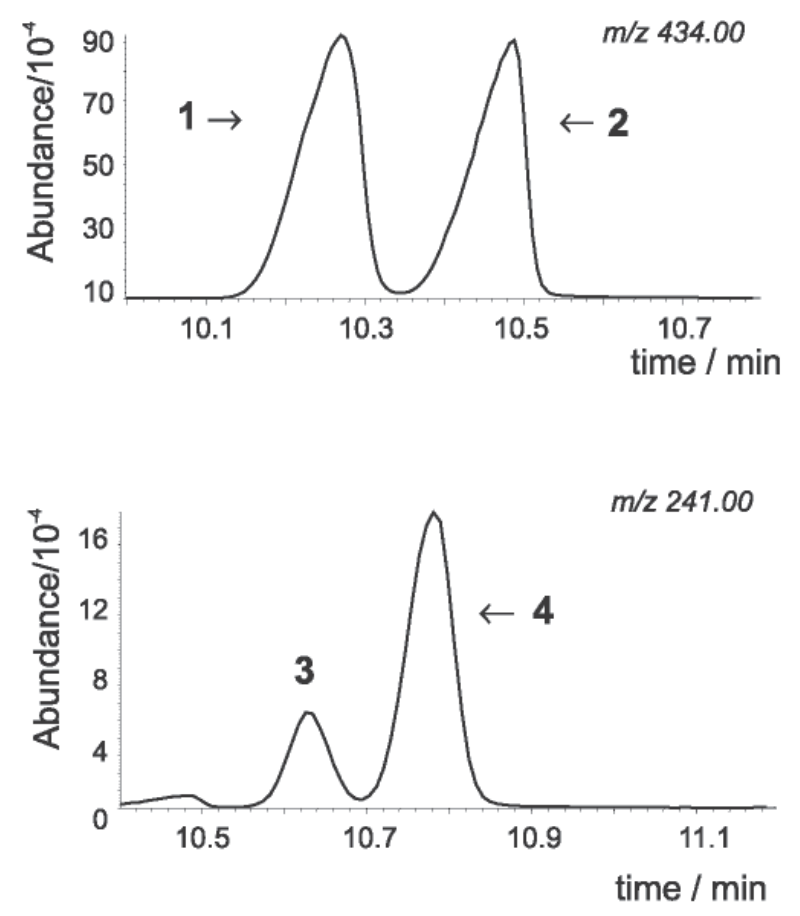

$m / z 522.00$

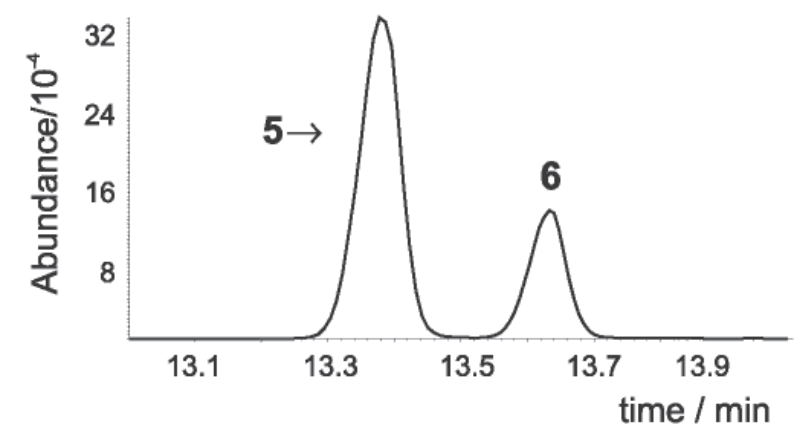

Figure 1. GC-MS chromatograms SIM mode. Temperature program from (a) $140{ }^{\circ} \mathrm{C}, 40{ }^{\circ} \mathrm{C} \min ^{-1}$ to $180{ }^{\circ} \mathrm{C}$ and $3{ }^{\circ} \mathrm{C} \min ^{-1}$ to 240 and $40{ }^{\circ} \mathrm{C}$ min ${ }^{-1}$ to $300{ }^{\circ} \mathrm{C}$ (held $3 \mathrm{~min}$ ), (b) $180{ }^{\circ} \mathrm{C}$ and $3{ }^{\circ} \mathrm{C} \mathrm{min}-1$ to 240 and $40^{\circ} \mathrm{C} \mathrm{min}^{-1}$ to $300{ }^{\circ} \mathrm{C}$ (held $3 \mathrm{~min}$ ) of a urine with a high density, (1) androsterone, (2) etiocholanolone, (3) $3 \alpha, 5 \alpha$-DIOL, (4) $3 \alpha, 5 \beta$-DIOL, (5) OHA and (6) OHE.

Some severely degraded urines $(n=7)$ with mean specific gravity of 1.020 (S.D. $=0.01$ ) and $\mathrm{pH}$ of $8.8 \pm$ 0.57 (mean \pm S.D.) were chosen to demonstrate the separation obtained between $5 \alpha$-androstan-3,17-dione and epitestosterone (Figure 3).

Disturbing polar substances, vitamins and metabolites of some drugs

Trimethopim and sulfamethoxazol are eluted in the same region where many endogenous steroids are detected. ${ }^{21-23}$ They may disturb the chromatography of endogenous compounds and lead to wrong interpretation. The behaviour was the same for both situation.

Urine with high specific gravity value

Urine with specific gravity higher than the normal 1.020 could have some influence in the shape of the endogenous steroids peaks usually to due they are excreted in high concentration in this kind of urine. To test the robustness of the chromatografic separations, six urines having high specific gravity (mean \pm S.D. $=$ 
Figure 4 showed that the main endogenous steroids are still well separated.

\section{Influence of the reactivity of the injection chamber}

As reported earlier the quality of glass liner and glass wool could influence the shape of the steroid peaks as the reactivity of these parts increases with number of injections. ${ }^{32}$ Figure 5 shows that the shape of $3^{\prime} \mathrm{OH}-$ stanozolol as not affected after 182 injections, i.e. after 7 batches of routine samples.

\section{Resolution of some key exogenous anabolic agents}

Using initial column temperature of $140{ }^{\circ} \mathrm{C}$ it is possible to obtain narrower initial analyte distributions
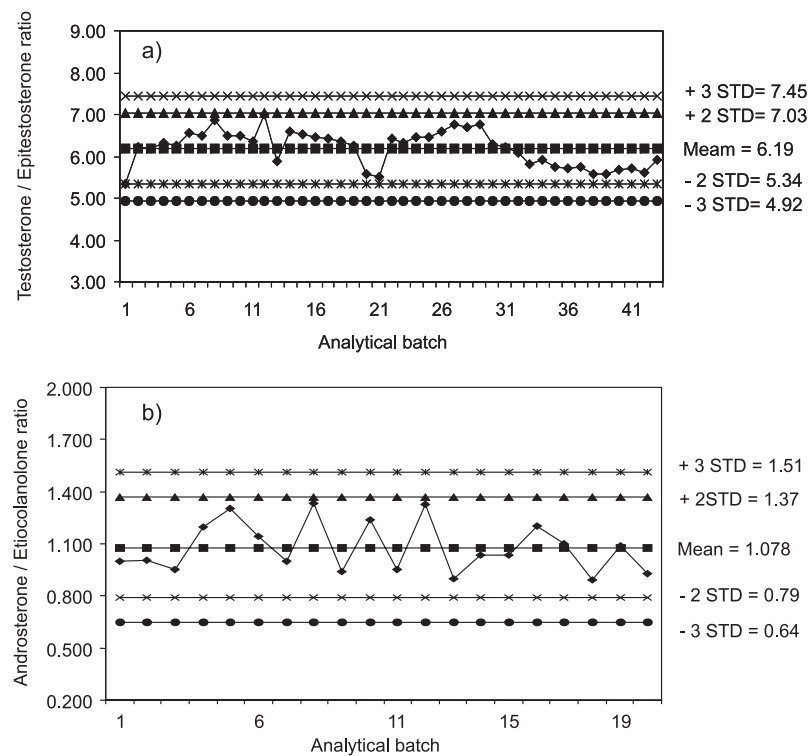

Figure 2. Shewhart control chart of (a) Testosterone / epitestosterone ratio (measured by area in QCAT) and (b) androsterone/etiocolanolone measured by area of a positive control (STDALL) fortified with the main endogenous substances at the cut-off concentration.

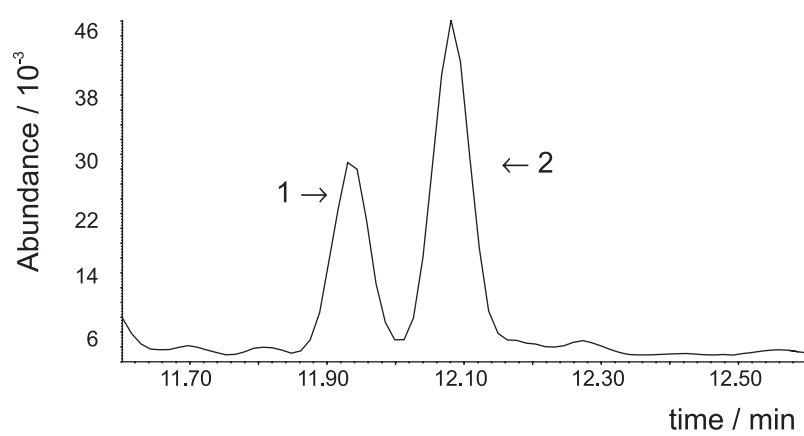

Figure 3. GC-MS $m / z, 432$ fragmentogram. Temperature program from $140{ }^{\circ} \mathrm{C}, 40{ }^{\circ} \mathrm{C} \mathrm{min}^{-1}$ to $180{ }^{\circ} \mathrm{C}$ and $3{ }^{\circ} \mathrm{C} \mathrm{min}^{-1}$ to 240 and $40{ }^{\circ} \mathrm{C} \mathrm{min}{ }^{-1}$ to 300 ${ }^{\circ} \mathrm{C}$ (held $3 \mathrm{~min}$ ) of a bacterially altered a urine. Specific gravity 1.026 and pH 9; (1) $5 \alpha$-androstanedione (2) epitestosterone. for the compounds that elutes at the beginining of the chromatogram (Figure 6).

\section{Conclusions}

The main objective for the presentation of the present results of improvements in steroid screening in doping control with special emphasis to GC-MS analytical conditions and method validation was to underline that decreasing the initial oven temperature from $180{ }^{\circ} \mathrm{C}$ to $140{ }^{\circ} \mathrm{C}$ and mantaining the other temperature program conditions increased the resolution for compounds that elutes at the begnining the chromatogram as well the $\mathrm{S} / \mathrm{N}$ ratio whithout any loss of the

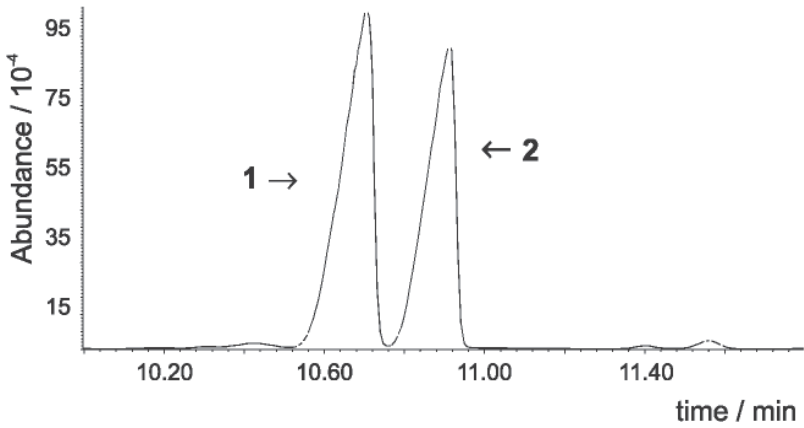

Figure 4. GC/MS $m / z 434$ fragmentogram of androsterone (1) and etiocholanolone (2) from analysis of an urine with specific gravity of $1.031 \pm 0.003$ and $\mathrm{pH} 5.17 \pm 0.26$. Data deriving from robustness test. Experimental conditions described in section 2.2.
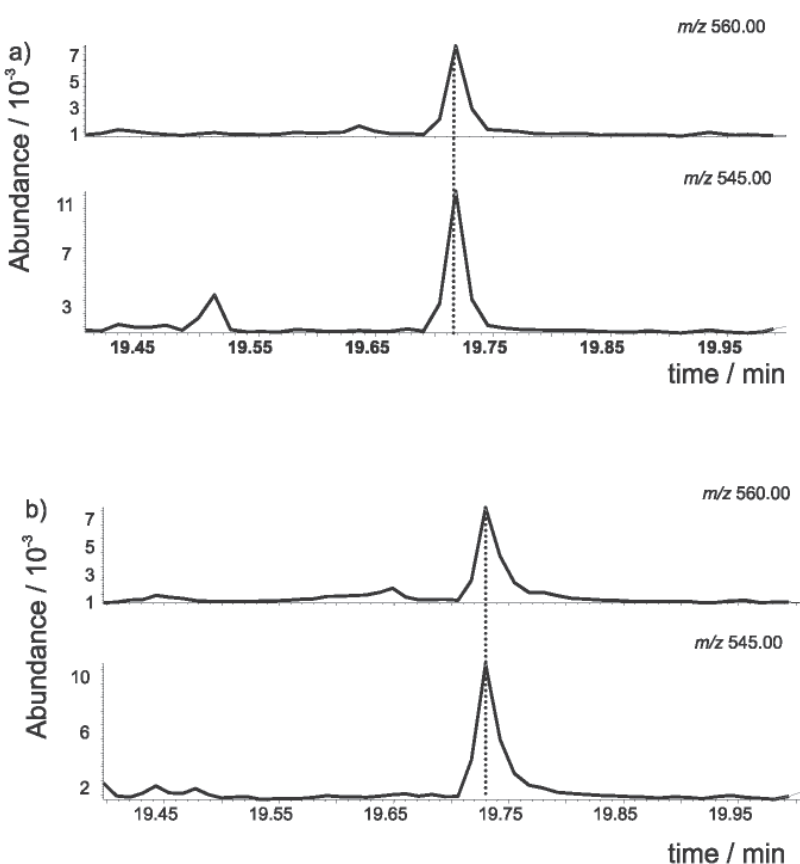

Figure 5. GC-MS $m / z 560$ and 545 fragmentograms analysis of a 3' $\mathrm{OH}-$ stanozolol* at the (a) first and (b) the one hundreth and eighty second injection after changing the liner. Normal routine urines were analyzed between these two.

*Positive control: $2 \mathrm{~mL}$ of urine fortified with exogenous steroids at 25 ng $\mathrm{mL}^{-1}$ of steroids. 
(A)
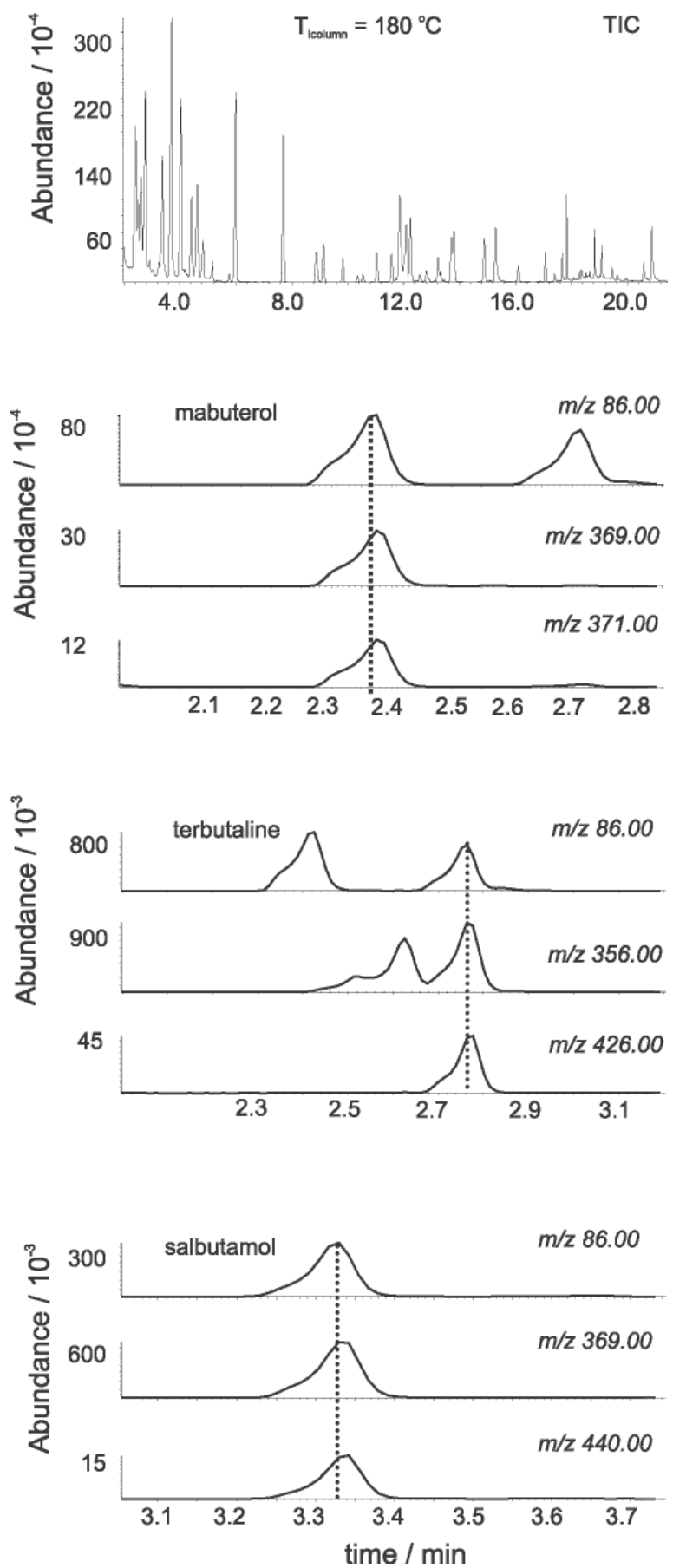

(B)
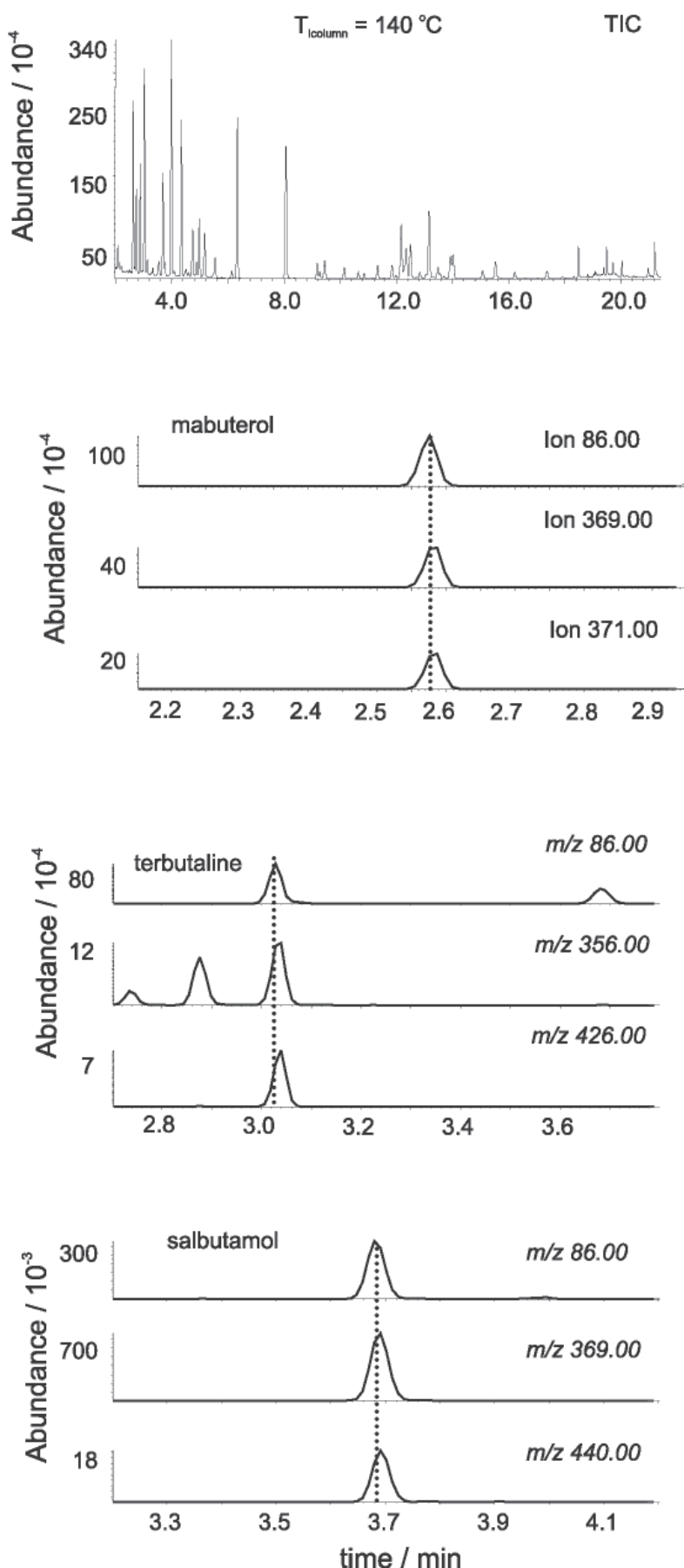

Figure 6. GC-MS chromatograms typical of urine samples (SIM mode). Temperature program from (A) $180{ }^{\circ} \mathrm{C}$ and $3{ }^{\circ} \mathrm{C}$ min ${ }^{-1}$ to $240,40{ }^{\circ} \mathrm{C}$ min ${ }^{-1}$ to 300 (held $3 \mathrm{~min}$ ) and (B) $140{ }^{\circ} \mathrm{C}, 40{ }^{\circ} \mathrm{C} \mathrm{min}^{-1}$ to $180{ }^{\circ} \mathrm{C}$ and $3{ }^{\circ} \mathrm{C} \mathrm{min}-1$ to $240,40{ }^{\circ} \mathrm{C} \mathrm{min}-1$ to 300 (held 3 min).

method performance. Therefore a larger number of compounds could be included in screening of anabolic agents, decreasing the cost of analysis.

\section{Acknowledgments}

CBF, FAPERJ, CNPq, CAPES and FUJB for financial support.

\section{References}

1. Ruth, S.; Ph.D. Thesis, Deutsche Sporthochschule Koln, Germany, 1994.

2. Nozaki, O.; J. Chromatogr., A 2001, 935, 267.

3. Shackleton, C. H. L.; J. Chromatogr. 1986, 379, 91.

4. Shahidi, N. T.; Clin. Ther. 2001, 23, 1355. 
5. Donike, M.; Rauth, S.; Wolansky, A. In Proceedings of the $10^{\text {th }}$ Cologne Workshop on Dope Analysis; Donike, M.; Geyer, H.; Gotzmann, A.; Mareck-Engelke, U., eds.; Sport and Buch Straub: Köln, 1993, p.69.

6. Schänzer, W.; Donike, M. In Proceedings of the $10^{\text {th }}$ Cologne Workshop on Dope Analysis; Donike, M.; Geyer, H.; Gotzmann, A.; Mareck-Engelke, U., eds.; Sport and Buch Straub: Köln, 1993, p.97.

7. Schänzer, W.; Donike, M.; Anal. Chim. Acta 1993, 275, 23.

8. Schänzer, W.; Clin. Chem. 1996, 42, 1002.

9. Geyer, H.; Schänzer,W.; Schindeler, U. In Recent Advances in Doping Analysis (3); Donike, M.; Geyer, H.; Gotzmann, A.; MareckEngelke, U., eds.; Sport and Buch Straub: Köln, 1996, p.215.

10. World Anti-Doping Agency. The 2005 Prohibited List. Montreal 2004

11. Donike, M.; Zimmermann, J.; J. Chromatogr. 1980, 202, 43.

12. Opfermann, G.; Schänzer, W. In Recent Advances in Doping Analysis (4); Donike, M.; Geyer, H.; Gotzmann, A.; MareckEngelke, U., eds.; Sport and Buch Straub: Köln, 1996, p. 247.

13. Huenerbein, A.; Marques, M. A. S.; Pereira, A. S.; Aquino Neto, F. R.; J. Chromatogr., A 2003, 985, 375.

14. Geyer, H.; Schänzer, W.; Mareck-Engelke, U.; Nolteersnsting, E.; Opfermann, G. In Recent Advances in Doping Analysis (5); Donike, M.; Geyer, H.; Gotzmann, A.; Mareck-Engelke, U., eds.; Sport and Buch Straub: Köln, 1998, p.99.

15. Antignac, J. P.; Bizec, B.; Monteau, F.; André, F.; Anal. Chim. Acta 2002, 224, 1.

16. International Organization and Standartization: ISO/11843-1, Capability of Detection (Part 1): Terms and Definitions, International Organization for Standardization, 1997.

17. Guindance for Industry: Bioanalytical Methods Validation for Human Studies, Center of Drug Evaluation and Research: Rockville, 1998.

18. Shah, V.P.; Midha, K.K.; Dighe, S.; McGilvery,, I.J.; Skelly, J.P.; Yacobi, A.; Layoff, T.; Viswanathan, C.T.; Cook, C.E.; McDowal, R.D.; Pitman, K.A.; Spector, S.; Pharm. Res. 1992, 9, 588.

19. Causon, R.; J. Chromatogr., B 1997, 689, 175.

20. Wieling, J; Hendriks, G.; Tamminga, W. J.; Hempenius J.; Mensink, C. K.; Oosterhuis, B.; Jonkman, J. H. G.; J. Chromatogr., A 1996, 730, 381.

21. Geyer, H.; Mareck-Engelke, U.; Schänzer, W.; Donike, M. In Recent Advances in Doping Analysis (1); Donike, M.; Geyer, H.; Gotzmann, A.; Mareck-Engelke, U., eds.; Sport and Buch Straub: Köln, 1994, p.91.
22. Geyer, H.; Schänzer, W.; Mareck-Engelke, U.; Donike, M. In Recent Advances in Doping Analysis (3); Donike, M.; Geyer, H.; Gotzmann, A.; Mareck-Engelke, U., eds.; Sport and Buch Straub: Köln, 1996, p.95.

23. Marques, M.A.S.; Bizarri, C.H.B.; Cardoso, J.N.; Aquino Neto, F.R. In Recent Advances in Doping Analysis (7); Donike, M.; Geyer, H.; Gotzmann, A.; Mareck-Engelke, U., eds.; Sport and Buch Straub: Köln, 1999, p.317.

24. Mareck-Engelke, U.; Geyer, H.; Donike, M. In Recent Advances in Doping Analysis (2); Donike, M.; Geyer, H.; Gotzmann, A.; MareckEngelke, U., eds.; Sport and Buch Straub: Köln, 1995, p.121.

25. Mareck-Engelke, U.; Geyer, H.; Schänzer, W. In Recent Advances in Doping Analysis (5); Donike, M.; Geyer, H.; Gotzmann, A.; Mareck-Engelke, U., eds.; Sport and Buch Straub: Köln, 1998, p.51.

26. Marques, M.A.S.; Geyer, H.; Schänzer, W.; Opfermann, G.; Pereira, H.M.G.; Aquino Neto, F.R. In Recent Advances in Doping Analysis (11); Donike, M.; Geyer, H.; Gotzmann, A.; MareckEngelke, U., eds.; Sport and Buch Straub: Köln, 2003, p.277.

27. de la Torre, R.; de la Torre, X.; Alia, C.; Segura, J.; Baro, T.; Torres-Rodriguez, J.M.; Anal. Biochem. 2001, 289, 116.

28. Ayotte, C.; Charlebois, A.; Lapointe, S.; Barriault, D.; Sylvestre, M. In Recent Advances in Doping Analysis (4); Donike, M.; Geyer, H.; Gotzmann, A.; Mareck-Engelke, U., eds.; Sport and Buch Straub: Köln, 1997, p.127.

29. Cardoso, C.R.; Marques, M.A.; Caminha, R.C.; Maioli, M.C.; Aquino Neto, F.R.; J. Chromatogr., B 2002, 775, 1.

30. Marques, M.A.S.; Geyer, H.; Schänzer, W.; Opfermann, G.; Pereira, H.M.G.; Aquino Neto, F.R. In Recent Advances in Doping Analysis (11); Donike, M.; Geyer, H.; Gotzmann, A.; MareckEngelke, U., eds.; Sport and Buch Straub: Köln, 2003, p.277.

31. Donike, M. In Proceedings of the 10th Cologne Workshop on Dope Analysis; Donike, M.; Geyer, H.; Gotzmann, A.; MareckEngelke, U., eds.; Sport and Buch Straub: Köln, 1993, p.47.

32. Catlin, D.H.; Lederc, B.Z.; Ahrensa, B.D.; Hattona, C.K.; Finkelsteinc, J.S.; Steroids 2002, 67, 559.

33. Ayotte, C.; Charlebois, A.; Goudreault, D.; Lévesque, C. In Recent Advances in Doping Analysis (2); Donike, M.; Geyer, H.; Gotzmann, A.; Mareck-Engelke, U., eds.; Sport and Buch Straub: Köln, 1995, p.375.

Received: April 1, 2005

Published on the web: February 24, 2006 